\title{
Erratum to: Associations Between Effortful Control, Psychological Control and Proactive and Reactive Aggression
}

\author{
Jamie Rathert $\cdot$ Paula J. Fite $\cdot$ Alden E. Gaertner $\cdot$ Michael Vitulano
}

Published online: 22 October 2011

(C) Springer Science+Business Media, LLC 2011

\section{Erratum to: Child Psychiatry Hum Dev DOI 10.1007/s10578-011-0236-3}

Unfortunately, the name of the fourth author, Michael Vitulano, was inadvertently omitted from the original version. The correct and complete author list is provided in this erratum.

The online version of the original article can be found under doi:10.1007/s10578-011-0236-3.

J. Rathert $(\bowtie)$ - P. J. Fite · A. E. Gaertner · M. Vitulano

Department of Psychology, The University of Tennessee, Austin Peay Building,

1404 Circle Dr., Knoxville, TN 37996, USA

e-mail: jrathert@utk.edu 